\section{Sprawozdanie z dorocznej konferencji międzynarodowego zrzeszenia ATLAS: „Sprzedawać czy opowiadać? \\ Paradoksy w turystyce, kulturze oraz dziedzictwie", Brighton, 2-4 lipca 2008 r.}

\section{Report from the Annual ATLAS Conference: 'Selling or Telling? Paradoxes in Tourism, Culture and Heritage', Brighton, 2nd $4^{\text {th }}$ July 2008}

2-4 lipca 2008 r. odbyla się tradycyjna, doroczna konferencja naukowa międzynarodowego zrzeszenia szkół wyższych zajmujących się kształceniem na potrzeby turystyki ATLAS ${ }^{1}$ poświęcona roli i znaczeniu dziedzictwa kulturowego w rozwoju turystyki. Organizatorzy spotkania przyjęli założenie, że istnieje przestrzeń do wymiany myśli i poglądów pomiędzy zagadnieniami dotyczącymi komercyjnego i tradycyjnego wykorzystania dziedzictwa kulturowego przez turystykę. Po raz pierwszy w historii ATLAS-u konferencję zorganizowano w Wielkiej Brytanii. Miejscem konferencji było Brighton, jeden $\mathrm{z}$ najbardziej znanych i tradycyjnych angielskich kurortów nadmorskich. Organizatorem z ramienia ATLAS-u był Uniwersytet w Brighton, we współpracy z Centrum Badań nad Polityką Turystyczną (CENTOPS - Center for Tourism Policy Studies) i Cultural Business - Impact, Strategy and Technology Management (CUBIST) Research Group, które mają swoje siedziby w Uniwersytecie w Brighton. Zgodnie z tradycją, konferencje ATLAS-u skupiaja nie tylko naukowców, ale i praktyków, którzy reprezentują różnego rodzaju instytucje zajmujące się rozwojem turystyki. Program konferencji podzielony był na sesje plenarne, warsztatowe oraz spotkania robocze grup badawczych, które funkcjonuja w ramach ATLAS-u.

Konferencję rozpoczęli krótkim wstępem doktorzy Nigel Jarvis i Jaime Kamiński z Uniwersytetu w Brighton, którzy w imieniu organizatorów poprosili Przewodniczącą ATLAS-u Melanie Smith o oficjalne otwarcie obrad. Następnie prof. Peter Burns, wieloletni przedstawiciel i koordynator współpracy ATLAS-u z Unią Europejską, przedstawił dr. Juliana Cramptona, wicekanclerza Uniwersytetu w Brighton, który w imieniu władz uniwersyteckich przywitał uczestników konferencji. Po części oficjalnej miała miejsce pierwsza sesja plenarna. Zwyczajowo podczas sesji plenarnych występują specjalnie zaproszeni przez ATLAS goście, którzy w swoich wy-
The traditional annual conference of ATLAS ${ }^{1}$, an international association of universities specializing in tourism education, took place from $2^{\text {nd }} 4^{\text {th }}$ July 2008. It was devoted to the role and significance of cultural heritage in tourism development. The organizers hoped that space would be made available for exchanging ideas on the commercial and traditional exploitation of cultural heritage by tourism. For the first time in the history of ATLAS the conference was held in Great Britain, in Brighton, one of the best-known English seaside resorts. The organizers were the University of Brighton, representing ATLAS, and also the Centre for Tourism Policy Studies (CENTOPS) and the Cultural Business - Impact, Strategy and Technology Management (CUBIST) Research Group, both based at the University of Brighton. Traditionally, ATLAS conferences attract not only academics but also practitioners representing various kinds of tourism institutions. The conference was divided into plenary sessions, workshops and meetings of those research groups which function within the ATLAS frame work.

The conference started with a short introduction by Dr Nigel Jarvis and Jaime Kaminski from the University of Brighton who, on behalf of the organizers, asked the ATLAS Chairwoman, Melanie Smith to officially open the event. After that, Prof. Peter Burns, representative and coordinator of cooperation between ATLAS and the European Union, introduced $\mathrm{Dr}$ Julian Crampton, the vice-chancellor of the University of Brighton, who welcomed conference participants on behalf of the university authorities. After the official opening, the first plenary session took place. During these sessions lectures are given by special guests who present a variety of ideas related to the main theme of the conference. The 
stapieniach prezentują koncepcje, rozwiązania, założenia o charakterze ogólnym nawiązujące do głównego tematu konferencji. Jako pierwszy wystapił prof. Gregory Ashworth z Uniwersytetu w Groningen. Tematem jego wystapienia były paradygmaty i paradoksy w planowaniu przeszłości. Generalnie referat odnosił się do planowania wykorzystania dziedzictwa kulturowego nie tylko na potrzeby turystyki. Autor skupił się głównie na sprzecznościach, jakie jego zdaniem pojawiają się w pojmowaniu tego, czym jest $\mathrm{z}$ jednej strony ochrona, a czym zachowanie wartości dziedzictwa kulturowego dla przyszłych pokoleń. Próbując rozwiązać ten problem, prof. George Ashworth zwrócił uwage głównie na celowość podejmowania działań, które w założeniu mają chronić dziedzictwo kulturowe. Jednocześnie stwierdzil, że należy bardziej efektywnie prowadzić działania w zakresie ochrony dziedzictwa kulturowego, angażując do nich m.in. turystów. Zdaniem prof. Georga Ashwortha, dziedzictwo nie powinno być postrzegane z perspektywy konkretnego miejsca czy obiektu, ale przede wszystkim jako proces, który wykorzystuje te obiekty i miejsca do przeniesienia idei z nimi związanych na grunt ushug zaspokajajacych potrzeby turystów.

Następnie odbyły się dwie sesje warsztatowe. W ciągu jednej godziny równolegle odbywało się pięć sesji warsztatowych. W pierwszej turze tematyka warsztatów skupiona była wokół zagadnień marketingu turystycznego, badań społeczno-ekonomicznych nad dziedzictwem kulturowym, stanu zachowania i tożsamości tego dziedzictwa oraz konfliktów wynikających $\mathrm{z}$ korzystania $\mathrm{z}$ jego wartości. $\mathrm{Z}$ kolei $\mathrm{w}$ drugiej turze wystapienia dotyczyły określenia roli obiektów światowego dziedzictwa kulturowego, a także różnego rodzaju wydarzeń kulturalnych, zwłaszcza festiwali w rozwoju turystyki. Ponadto tematyka pozostałych sesji warsztatowych związana była $\mathrm{z}$ zagadnieniami odnowy lokalnego dziedzictwa kulturowego przez turystykę, ponownie konfliktów funkcji pełnionych przez obiekty kulturowe oraz zastosowania współczesnych rozwiązań technologicznych w turystyce kulturowej. Pierwszego dnia konferencji została zorganizowana także interesująca wycieczka, której trasa prowadziła kanałami ściekowymi wybudowanymi w Brighton w drugiej połowie XIX w.

Następny dzień konferencji (3 lipca) rozpoczą się od sesji plenarnej, w której wystapił Nick Dodds, dyrektor zarządzający brytyjskim stowarzyszeniem „Międzynarodowe Festiwale i Wydarzenia". W swoim referacie zaprezentował zakres, wielkość i rozwój rozmaitych międzynarodowych first speaker was Prof. Gregory Ashworth from Groningen University who talked about the "paradigms and paradoxes in planning the past'. Generally, his lecture on planning the use of cultural heritage for purposes other than tourism focused on the contradictions which, to his mind, appeared in understanding the difference between the protection and the preservation of cultural heritage for future generations. Trying to resolve this problem, Prof. Ashworth stressed the appropriateness of activities which are supposed to protect cultural heritage. He also contended that cultural heritage protection should be more effective and that tourists should be involved in it. In his opinion, heritage should not be perceived from the point of view of a single site or building, because it is a process in which such sites and buildings are used to transfer ideas to the services satisfying tourist needs.

The lecture was followed by workshop sessions with five taking place simultaneously over one hour. In the first round they concerned tourism marketing, socio-economic research into cultural heritage, the state and identity of this heritage, as well as conflicts arising from its exploitation. In the second the presentations concerned the role of world cultural heritage items and various kinds of cultural events, festivals in particular, in tourism development. The topics of the remaining workshops were related to the renewal of local cultural heritage through tourism, again conflicts in the functions of specific cultural sites, as well as the use of modern technology in cultural tourism. On the first day of the conference the participants could also take part in an interesting excursion to the still-functioning sewers built in Brighton in the second half of the $19^{\text {th }} \mathrm{c}$.

The next day ( $3^{\text {rd }}$ July) started with a plenary session which featured a presentation by Nick Dodds, the director of a British association called 'International Festivals and Events'. He presented the range, scale and development of different international festivals and events in Great Britain, the problems of promoting this kind of event and their importance for tourism development. The presentation was very practical in nature.

The plenary session was followed by two rounds of workshops. In the first the presentations were on tourism marketing, the renewal of tourist seaside areas, and the interpretation of cultural heritage protection and identity. The second round presentations discussed mainly the management of cultural heritage. 
festiwali i wydarzeń na terenie Wielkiej Brytanii, problemy promocji tego rodzaju spotkań oraz ich znaczenie dla rozwoju turystyki przyjazdowej na wyspach brytyjskich. Wystapienie miało charakter bardzo praktyczny.

Następnie odbyly się kolejne dwie tury sesji warsztatowych. W pierwszej z nich referaty dotyczyły marketingu turystycznego, problemów odnowy turystycznych obszarów nadmorskich, interpretacji, ochrony i tożsamości dziedzictwa kulturowego. W drugiej turze z kolei mówiono głównie o rozwoju zarządzania dziedzictwem kulturowym.

Po zakończeniu warsztatów odbyła się kolejna sesja plenarna, w której wystapił prof. Mike Robinson z Centre for Tourism and Cultural Change, Leeds Metropolitan University. W referacie autor wyjaśniał sposoby postrzegania dziedzictwa kulturowego przez turystów oraz tych, którzy decydują o rozwoju turystyki związanej z dziedzictwem kulturowym. Jednocześnie zwrócił uwagę na sytuacje, w których prezentowanie (sprzedawanie) wartości dziedzictwa kulturowego jest zakłócane $\mathrm{z}$ jednej strony przez historię, a $\mathrm{z}$ drugiej przez rzeczywistość. Za przykład posłużyly autorowi antyczne ruiny jordańskiego miasta Um Qais (Mkies).

Ostatni dzień konferencji rozpoczął się od sesji plenarnej. Kolejnym zaproszonym przez organizatorów referentem był Michael Bedingfield, dyrektor Brytyjskiej Narodowej Organizacji Turystycznej „VisitBritain”, który omówił zagadnienia związane z turystyką przyjazdową na wyspy brytyjskie (wielkość, kierunki, struktura ruchu turystycznego, dochody z turystyki, perspektywy rozwoju) oraz z problemami dotyczącymi promocji dziedzictwa kulturowego kraju. Zdaniem autora, dziedzictwo kulturowe jest najważniejszym walorem turystycznym Wielkiej Brytanii.

W kolejnej turze warsztatów tematyka wystapień nie różniła się znacząco od poprzednich tego rodzaju sesji. Ogólnie referaty dotyczyły marketingu turystycznego miast, praktycznych aspektów polityki planowania na szczeblu lokalnym, regionalnym i narodowym, planowania odnowy dziedzictwa kulturowego oraz relacji pomiędzy turystami kulturowymi i odwiedzającymi. Tuż przed ostatnią turą sesji warsztatowych miała miejsce jeszcze jedna sesja plenarna, w której prof. John Tunbridge z Carleton University w Kanadzie zaprezentowal referat dotyczący problemów związanych z marketingiem dziedzictwa kulturowego z perspektywy obszarów peryferyjnych (wyspiarskich) Europy. Autor zwrócił uwagę głównie na utrudnienia $w$ rozwoju turystyki związanej z dziedzictwem kulturowym, które często
After the workshops, a further plenary session was held featuring a lecture by Prof. Mike Robinson from the Centre for Tourism and Cultural Change, Leeds Metropolitan University. He explained the ways cultural heritage is perceived by tourists and by those who make decisions about the development of heritage-related tourism. The author pointed out situations in which presenting (selling) the values of cultural heritage is disturbed by history on the one hand, and reality on the other. He used the example of the ancient ruins of the Jordan city of Um Qais (Mkies).

The last day of the conference started from a plenary session and a presentation by Michael Bedingfield, the director of the British National Tourist Organization 'Visit Britain', who discussed a number of issues concerning incoming tourism in Britain (the intensity, direction and structure, income generated by tourism, development prospects), as well as the problems of promoting its cultural heritage. In the speaker's opinion, cultural heritage is the most valuable British tourist asset. The topics discussed in the workshop session that followed were not much different from those presented in the previous sessions. The presentations concerned tourism marketing in cities, the practical aspects of local, regional and national planning policies, the planning of cultural heritage renewal, as well as the relation between cultural and other tourists. Before the last round of workshops there was one more plenary session, during which Prof. John Tunbridge from Carleton University in Canada presented a paper concerning cultural heritage marketing from the point of view of the peripheral island areas of Europe. The author pointed to obstacles in cultural heritage tourism development which often cause conflicts. On the other hand, the author expressed his belief in a cultural heritage management which guarantees responsibility for this heritage, taken both by tourist institutions and local communities.

The conference ended with one more round of workshops, dealing with issues such as the contradictory needs of tourism and cultural heritage, the diversification and renewal of cultural heritage tourism, conflicts over heritage in Asia, the myths and truths about cultural heritage, as well as ethnic aspects of cultural heritage.

Apart from workshops and plenary sessions, Special Interest Group meetings are a regular element of the annual ATLAS 
są przyczyną konfliktów. Z drugiej strony wg autora istotnym jest takie zarządzanie dziedzictwem kulturowym, które daje gwarancje odpowiedzialności za to dziedzictwo zarówno ze strony podmiotów turystycznych, jak i lokalnej społeczności.

Na zakończenie merytorycznej części konferencji odbyła się jeszcze jedna tura warsztatów, podczas której zajmowano się takimi zagadnieniami, jak sprzeczne potrzeby turystyki i dziedzictwa kulturowego, zróżnicowanie i odnowa turystyki zwiazanej z dziedzictwem kulturowym, konflikty a dziedzictwo w Azji, mity i prawdy o dziedzictwie kulturowym oraz etniczne aspekty dziedzictwa kulturowego.

Poza sesjami warsztatowymi i plenarnymi stałym elementem programu dorocznych konferencji ATLAS-u są spotkania robocze grup zainteresowań (Special Interest Groups), które zorientowane są na tematykę o charakterze edukacyjnym i badawczym lub związane sa z określonym regionem. Obecnie (2008) w ATLAS-ie działa 12 tego rodzaju grup. Podczas tegorocznej konferencji odbyły się spotkania informacyjne inicjujące powstanie kolejnej grupy zainteresowań, która zajmować się będzie turystyką sportową.

Ogółem w tegorocznej konferencji ATLAS-u wzięło udział 140 osób z 33 krajów. Najwięcej uczestników, co zrozumiałe, było z Wielkiej Brytanii. Stosunkowo dużo osób przyjechało z Holandii, Dani, Włoch, Australii, Nowej Zelandii, Portugalii, Finlandii, Belgii czy Grecji. Uczestniczyli również koledzy i koleżanki z Japonii, USA, Kanady, Tajlandii, RPA, Kenii, Egiptu, Tajwanu, Indonezji, Cypru oraz z Polski, Rumunii, Węgier, Lotwy, Bułgarii i Turcji.

Konferencja pod patronatem ATLAS-u została zorganizowana przez pracowników i studentów Uniwersytetu w Brighton. Następne tego typu spotkanie odbędzie się w maju 2009 r. w Alborgu w Danii.

\section{PRZYPIS}

${ }^{1}$ Association for Tourism and Leisure Education utworzono w 1991 r. jako organizację zrzeszająca szkoły wyższe kształcące w zakresie turystyki i rekreacji. Stowarzyszenie powstało najpierw w Europie, a ostatnio na pozostałych kontynentach. Do ATLAS-u zaczęły przystępować instytucje niezajmujące się działalnością edukacyjna, lecz tylko badaniami naukowymi w zakresie turystyki i rekreacji oraz reprezentujące przemysł turystyczny (BACHVAROV 2003). Obecnie ATLAS liczy ponad 300 czlonków.

\section{BIBLIOGRAFIA}

BaChVAROv M., 2003, Międzynarodowe zrzeszenie szkól wyższych ksztalcqcych dla $w$ zakresie turystyki i rekreacji ATLAS, Turyzm, t. 13, z. 2. conferences oriented towards educational and research issues alike, or a particular region. Currently (2008) ATLAS comprises 12 such groups and this year a meeting initiating a new Special Interest Group was held dealing with issues in sports tourism.

All in all, this year's ATLAS conference hosted 140 participants from 33 countries, with a majority from Great Britain. A relatively large number arrived from the Netherlands, Denmark, Italy, Australia, New Zealand, Portugal, Finland, Belgium or Greece. Others came from Japan, the USA, Canada, Thailand, South Africa, Kenya, Egypt, Taiwan, Indonesia, Cyprus, Poland, Romania, Hungary, Latvia, Bulgaria and Turkey.

The ATLAS conference was organized by the employees and students from the University of Brighton. The next meeting of this type will be held in May 2009 in Aalborg, Denmark.

\section{FOOTNOTE}

\begin{abstract}
1 The Association for Tourism and Leisure Education was established in 1991, originally as an organization uniting universities that taught tourism and recreation, first in Europe and lately also on other continents. Recently, ATLAS has been joined by non-educational institutions which are involved only in research into tourism and recreation, and which represent the tourist industry (BACHVAROV 2003). At present ATLAS has over 300 members.
\end{abstract}

\section{BIBLIOGRAPHY}

BACHVAROV, M., 2003, Międzynarodowe zrzeszenie szkót wyższych ksztakcacych dla w zakresie turystyki i rekreacji ATLAS, Turyzm, t. 13, z. 2.

\section{Robert Wiluś}

Instytut Geografii Miast i Turyzmu

Uniwersytetu Łódzkiego

ul. Kopcińskiego 31

90-142 Łódź

robwil@geo.uni.lodz.pl 